\title{
Quantification of nitrate fluxes to groundwater and rivers from different land use types
}

\author{
Dmytro DIADIN ${ }^{1}$, Yuliya VYSTAVNA ${ }^{1,2}$ and Yuri VERGELES ${ }^{1}$
}

\begin{abstract}
Nitrate enters aquatic systems from anthropogenic and natural sources affecting drinking water supply and surface water eutrophication. Conventional hydro-chemical measurements have been used together with the geographic information system (GIS) and stable isotopes techniques to track nitrate origin, sources distribution and quantify their fluxes from various land use types to ground and surface waters in East Ukraine. Average fluxes of nitrate in groundwater are estimated at $356 \mathrm{~kg}$ year-1 km-2 from settlements (mostly rural), $214 \mathrm{~kg}$ year ${ }^{-1} \mathrm{~km}^{-2}-$ from agricultural lands and $73 \mathrm{~kg}_{\text {year }} \mathrm{km}^{-2}$ - from forested areas. According to the mass balance estimation, nitrogen input $\left(150 \mathrm{~kg}_{\text {year }} \mathrm{km}^{-2}\right)$ occurs mainly in the upper part of the Seversky Donets River basin and is attributed to the discharge of untreated municipal wastewater to rivers as well as groundwater contamination by leaking septic tanks and pit latrines from residential areas.
\end{abstract}

Keywords: land use; nitrate contamination; GIS; Ukraine; stable isotopes of nitrate

\section{Introduction}

Nitrate contamination of groundwater is a rising problem worldwide (RivetT, M.O. et al. 2008; WHO 2011) that affects drinking water supply and leads to eutrophication of surface water that, in turn, poses environmental and human health risks (SLOMP, C.P. and VAN Cappellen, P. 2004; WHO 2011). Nitrates can enter both ground and surface water from both anthropogenic (sewage leakages, storages of fertilizers, manures, landfills, runoff from crop fields) and natural (forest soil, wetlands) sources (KATZ, B.G. et al. 2004; LOCKHART, K.M. et al. 2013; Vystavna, Y. et al. 2017a). Besides, nutrient input from agricultural soils to runoff and further to water bodies may be facilitated by soil erosion processes (GöNDöcs, J. et al. 2015). Depending on land use patterns, hydrogeological and denitrification conditions, nitrate ion in groundwater may be highly mobile and persistent (OuYANG, Y. 2012; YAKOvLEV, V. et al. 2015; Vystavna, Y. et al. 2017a, b). Conventional hydro-chemical measurements are not sufficient to track nitrate origin, sources distribution and to quantify fluxes from various land use types. However, additional tools such as the geographic information systems (GIS) allowing to define the land use types and drainage area for contaminants pathways (Vystavna, Y. et al. 2017a, b), and stable isotopes of nitrate allowing to identify dominant sources, can be useful to quantify nitrate fluxes in relation to the land use (Matiatos, I. 2016). Nitrate balance in soil-water systems together with other nutrient related indicators is also used for modelling ecosystem services (Макоvníková, J. et al. 2017). While some studies (OuYANG, Y. 2012; LockHART, K.M. et al. 2013; Matiatos, I. 2016) have provided good insights into nutrient loads from groundwater to surface waters, nitrate fluxes from different land use types are still poorly understood and rarely quantified.

\footnotetext{
${ }^{1}$ Department of Urban Environmental Engineering and Management, O.M. Beketov National University of Urban Economy in Kharkiv, 6 1002, Marshala Bazhanova Street 17, Kharkiv, Ukraine. E-mail: dmdyadin@gmail.com ${ }^{2}$ Biology Centre of the Czech Academy of Sciences, Institute of Hydrobiology, Na Sádkách 7, 37005 České Budějovice, Czech Republic. E-mail: yuliya.vystavna@hbu.cas.cz
} 
The combination of conventional hydrochemical measurements (water temperature, discharge, major ions) with stable isotopes of nitrate and the application of GIS tools has been used to quantify nitrate fluxes from the Kharkiv region in East Ukraine - the largest one, in a term of size and population. Our previous investigations (Vystavna, Y. et al. 2015; YaKovleV, V. et al. 2015; Vystavna, Y. et al. 2017a) have shown that about 20 per cent of groundwater samples taken in the Kharkiv region featured nitrate content at more than $50 \mathrm{mg} \mathrm{L}^{-1}$ being above a water quality limit established by the World Health Organization (WHO). The studied region is a relatively water scarce one and has very limited local runoff, with substantial part of water supply provided by water translocation from other Ukraine's river basins via artificial canals (Vystavna, Y. and Diadin, D. 2015). Additionally, the region is considered to be influenced by climate change that results in the deterioration of water quality (Pidlisnyuk, V.et al. 2016). Thus, knowledge on water contamination sources is urgently needed to secure drinking water supply, prevent the spread of water-related diseases and protect natural aquatic systems (CANTER, L.W. 1997; WHO 2008). The objective of the study was to quantify nitrate fluxes from settlements, forested and agricultural land use to ground and surface waters used for drinking water supply applying geochemical, stable isotopes of nitrates and GIS-based techniques.

\section{Methods and materials}

\section{Study area}

The area of the studied Kharkiv region of Ukraine (the population is ca. 2.7 million) is $31,415 \mathrm{~km}^{2}$. The dominant land use type is agricultural lands that cover 77 per cent of the territory. The rest of the area is covered by forests, dense urban, sub-urban and rural settlements (Figure 1). Grey forest and thick grassland soils, called chernozems, dominate in the study area (Vystavna, Y. et al. 2012) with average water infiltration rate about $2 \mathrm{~m}$ year ${ }^{-1}$ (Maslov, B.S. 2009).

Agricultural lands include arable areas (62\% of agricultural lands area), grasslands and pastures $(27 \%)$ and others (orchards, farms, etc.) (ECO, 2015). Inorganic fertilizers, mainly nitrogen, are applied at the rate of ca. $50 \mathrm{~kg} \mathrm{ha}^{-1}$, where most of them (88\%) are three-component (N, P and $\mathrm{K}$ ) and ammonium nitrate fertilizers (Vystavna, Y. et al. 2017a). Manure is applied as an organic fertilizer at small farms and individual rural and suburban households. About 90 per cent of wastewater in rural area is not treated and disposed to poor-isolated septic tanks and pit latrines from which it seeps into shallow groundwater (Vystavna, Y. et al. 2017a, b).

Approximately $2 / 3$ of the study area belongs to the Seversky Donets catchment, the Sea of Azov's basin, and the rest $1 / 3$ belongs to the Dnipro River basin. The Seversky Donets River is a transboundary Russian Federation/ Ukraine waterway with an average annual discharge of $12 \mathrm{~m}^{3} \mathrm{~s}^{-1}$ (upstream of the Kharkiv region). The Seversky Donets River is used for drinking and industrial water supply, but also for receiving both treated and untreated wastewaters. Untreated wastewater discharge is about $4-5 \mathrm{mln}^{3}$ year $^{-1}$ (ECO 2015). The river is of alluvial character and is mainly recharged by precipitation (65\%) and groundwater (up to $35 \%$ ). Within the study area, the surficial geology up to $120 \mathrm{~m}$ of depth is composed mostly of permeable and loose sedimentary materials - sands, loams and clayey loams of Quaternary, Neogene and Paleogene ages. The presence of hydraulic connectivity between surficial Quaternary aquifers including the Upper Cretaceous formations results in a wide range of groundwater geochemistry (Vystavna, Y. et al. 2015). The shallow aquifer lies at 5-30 $\mathrm{m}$ below the surface in sands or sandy loams and outflows as numerous springs to main and tributary river valleys. High share of groundwater in the river's recharge indicates that surface water chemistry is influenced by chemical fluxes from the shallow aquifer (YAKOVLEV, V. et al. 2015). 


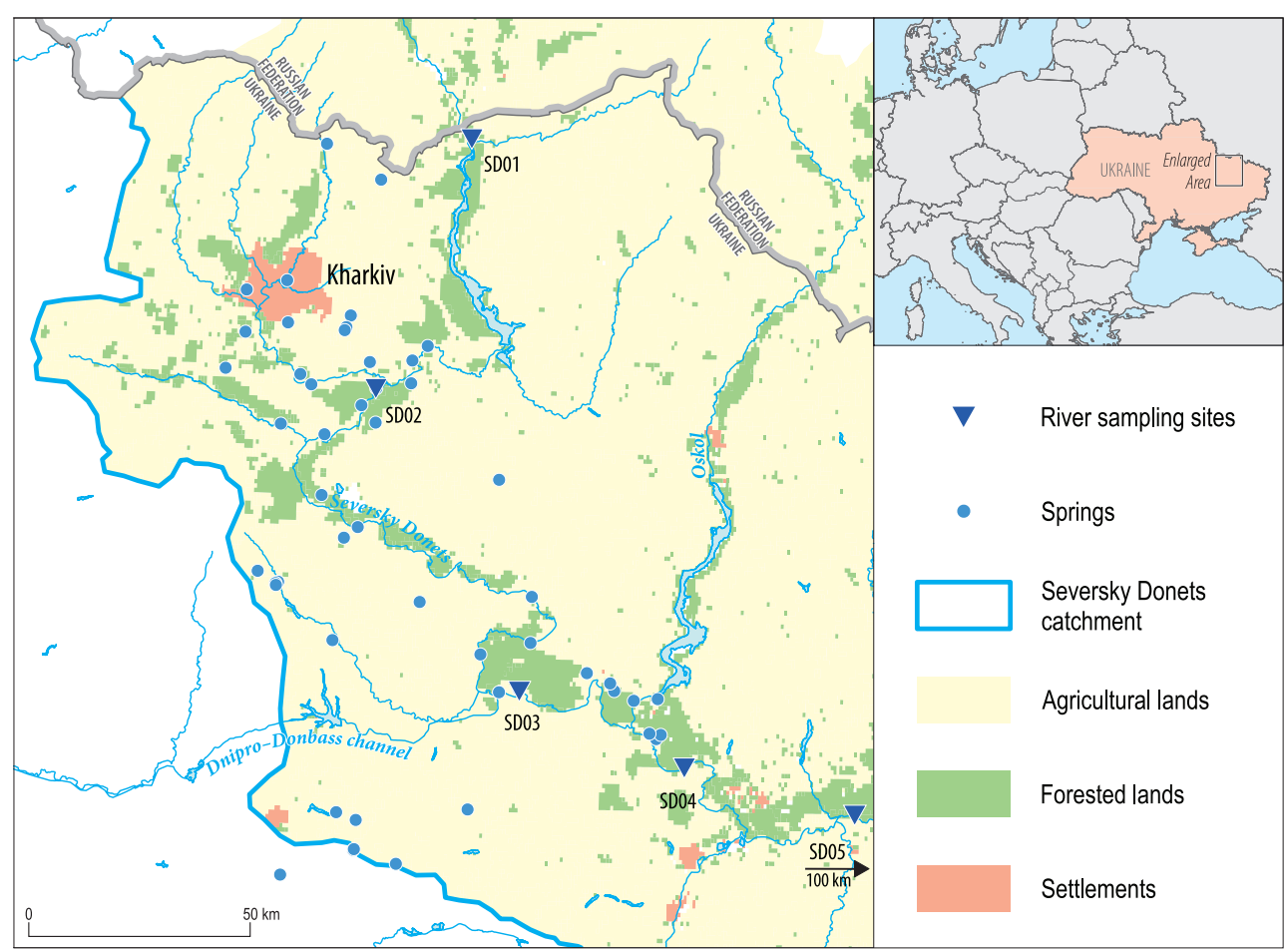

Fig. 1. The study sites location and major land uses in the Kharkiv region, East Ukraine

\section{Sampling and analysis}

In total, 50 groundwater-driven springs and 4 surface water sites were sampled in the studied area. Groundwater discharge rates were measured with a stopwatch and a calibrated container during the sampling. Water temperature, $\mathrm{pH}$, electrical conductivity (EC) and redox potential (ORP) were measured in the field applying HI-98130 Multi-parameter tester and ORP (Redox) Tester 98121 (Hanna Instruments (B). Major ions (calcium, hydrocarbonate, magnesium, chloride, sulphate, sodium, potassium and nitrate) were analysed using the potentiometric method (described in YAKOVLEV, V. et al. 2015, and Vystavna, Y. et al. 2017a). In order to trace dominant nitrate sources in the study area, 8 springs selected from different land use types were additionally sampled on stable isotopes of nitrate. For this purpose, water samples were filtered $(0.22 \mu \mathrm{m})$ in the field and transferred into $50 \mathrm{~mL}$ plastic bottles. Nitrogen $\left(\delta^{15} \mathrm{~N}-\mathrm{NO}_{3}\right)$ and oxygen $\left(\delta^{18} \mathrm{O}-\mathrm{NO}_{3}\right)$ isotopes of nitrate were analysed using the denitrifying method (described in Vystavna, Y. et al. 2017a). $\mathrm{N}$ and $\mathrm{O}$ isotope ratios were reported as $\delta$ values as a part per thousand (\%o) deviations relative to the standards: atmospheric $\mathrm{N}_{2}$ (AIR) for nitrogen and Vienna Standard Mean Ocean Water (V-SMOW) for oxygen:

$$
\delta(\% o)=\left[\left(R_{\text {sample }}-R_{\text {standard }}\right) / R_{\text {standard }}\right] \times 1000,
$$

where $R$ is the ratio of the heavy to light isotopes as ${ }^{15} \mathrm{~N} /{ }^{14} \mathrm{~N}$ or ${ }^{18} \mathrm{O} /{ }^{16} \mathrm{O}$.

\section{Data treatment and nitrate fluxes estimation}

The GIS software (ArcGIS 10.2.2) was used to delineate catchment area of each sampling site basing on digital elevation model (RAwAT, 
K.S and Singh, S.K. 2018). Land cover types were defined from the Global Land Cover database of Europe (GLC 2000). The groundwater sampling sites were grouped according to the sub-catchments of the Seversky Donets River: SD01-SD02 represents the upper part of the basin, from the entrance to Ukraine and before the conjunction with the Udy River (flowing through the Kharkiv metropolitan area); SD02-SD03 represents the area downstream the city of Kharkiv, with treated wastewater discharges and upstream inflow of the artificial canal that transfers water masses from the Dnipro River basin; SD03SD04 is a part of basin that lies between the inflow of the Dnipro-Donbas artificial canal and the conjunction with the Oskol River at the border of the Kharkiv and Donetsk regions; SD04-SD05 is a lower part of the studied basin, downstream the conjunction with the Oskol River (see Figure 1).

The studied groundwater springs were classified into three groups according to dominant land use types in their catchment areas: 16 groundwater-driven springs with drainage areas within the agricultural lands (AG), 18 springs - within the forest areas (FR) and 16 springs - within the settlements (SE). Software package Golden Software Grapher 12.0 was applied for data plotting.

Nitrate fluxes from a ground to surface waters were estimated using the following equation (YAKOVLEV, V. et al. 2015):

$$
F_{\mathrm{NO} 3}=Q \times C \times K / S,
$$

where, $F_{\mathrm{NO} 3}$ is an annual flux of nitrate, $\mathrm{tkm}^{-2}$ $\mathrm{y}^{-1}, Q$ is a measured ground water discharge, $\mathrm{Ls}^{-1}, C$ is the analysed nitrate concentration, $\mathrm{mgL}^{-1}, K$ is seconds per year $(31,536,000 \mathrm{~s})$, and $S$ is an estimated drainage area, $\mathrm{km}^{2}$, following the equation:

$$
S=Q / M,
$$

where $M$ is the groundwater flow module, projected according to the average river flow rate of 90 per cent of water availability $(M=$ $1.25 \mathrm{Ls}^{-1}$ ) (YAKovLEV, V. et al. 2015).

Specific fluxes of nitrate were estimated for the springs grouped according to the dominant land use in their drainage areas. The values of specific fluxes were calculated as average values for the group of springs in each land use type. Fluxes for the nitrate nitrogen were calculated according to the molecular ratio $(14 / 62)$ and normalized by the sub-catchment area.

\section{Results and discussions}

\section{General chemistry of groundwater}

Among 50 studied springs, more than 60 per cent had groundwater discharge less than $0.5 \mathrm{Ls}^{-1}$ (Figure 2, a). Groundwater temperature, EC and ORP were highly variable (Figure 2, b)

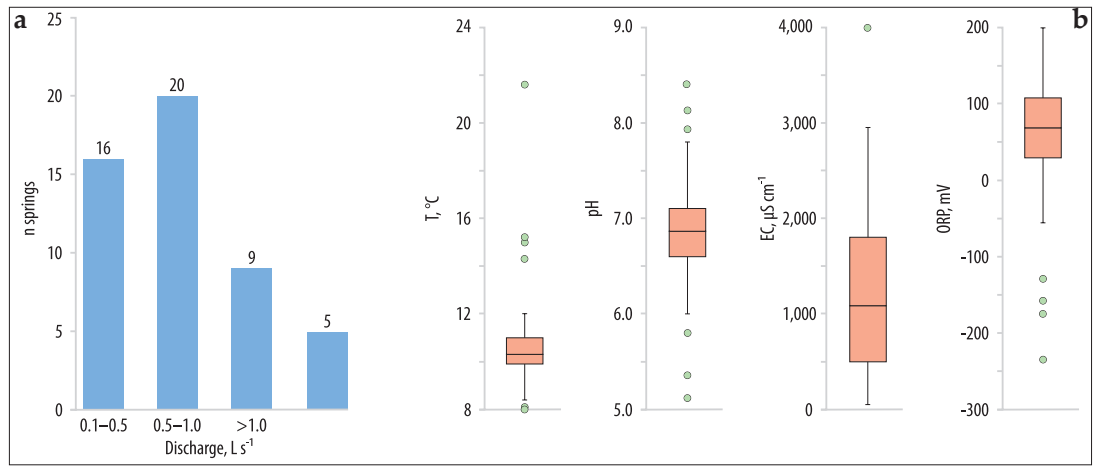

Fig. 2. Distribution chart of measured groundwater discharge rates, $\operatorname{Ls}^{-1}$ (a), and box plots of measured hydro-chemical parameters of groundwater $(\mathrm{b})$ 
indicating different hydrogeological and land use conditions (Vystavna, Y. et al. 2015).

Major ion composition of groundwater was significantly varying, too, with the prevalence of $\mathrm{Ca}-\mathrm{HCO}_{3}(46 \%)$ and $\mathrm{Na}-\mathrm{Ca} \mathrm{Cl}-\mathrm{SO}_{4}$ (42\%) groundwater types (Figure 3, a).

The studied sub-catchments clear differed by their hydrochemistry (Figure 3) with prevalence of $\mathrm{Ca}-\mathrm{HCO}_{3}$-type groundwater in the upper SD01-SD02 and $\mathrm{Ca}-\mathrm{Cl}-\mathrm{SO}_{4}-$ type groundwater in the lower SD04-SD05 sub-basins. However, in the SD02-SD03 and SD03-SD04 sub-catchments, both sulphateand bicarbonate-dominated groundwater types were found (Figure 3, b).

Among cations, calcium dominated in the majority of samples $(86 \%)$, while sodium dominated only in 14 per cent of samples (Figure 3, a). Among anions, the gradual increase of $\mathrm{Cl}^{-}$and $\mathrm{SO}_{4}{ }^{2-}$ was detected from upstream to downstream sub-catchments (Figure 3, b). This can be attributed to the lithology of vadose zone and aquifers, but also to the continuous discharge of wastewaters. The $\mathrm{Ca}-\mathrm{HCO}_{3}$ groundwater type is consistent with the lithology nature of the river beds and explains water-rock interaction with the Cretaceous carbonate rocks (Vystavna, Y. et al. 2015). At the lower part of the water basin, $\mathrm{Cl}^{-}$and $\mathrm{SO}_{4}{ }^{2-}$ composition of groundwater can be associated with natural (interaction with halite and gypsum inclusions in clays) and anthropogenic factors (wastewater discharges). Previous estimations of the groundwater saturation index within the study basin indicated its under-saturation with halite confirming the minor role of this geological structure in the groundwater chemistry (Vystavna, Y. et al. 2015). Besides, upward recharge from deeper salty Triassic aquifers would be an additional source of chlorides in this area. In southern part of the region, sulphate minerals (such as gypsum and anhydrite) were found in the uppermost layers of Quaternary deposits and could be suggested an additional source for this anion in groundwater (VystavnA, Y. et al. 2015). However, the water-rock interaction and upward recharge are needed to be additionally studied. Similarly, to springs, $\mathrm{Cl}^{-}$ increases downstream the Seversky Donets River together with rising of total dissolve solids (TDS) values (Figure 3, a).

\section{Land use and dominant sources of nitrate}

GIS-analysis of Global Land-Cover datasets indicated three dominating land use types in the studied basin: agricultural lands (including arable lands, pastures and grasslands), forested areas and settlements (both rural and urban) (Figure 1). Measuring contents of stable isotopes of nitrate in groundwater from settlements, agricultural and forested areas revealed that manure and sewage were dominant sources of nitrate in the Seversky Donets basin (Figure 4), in the agreement with our previous study (Vystavna, Y. et al. 2017a).

Domination of manure and sewage among other groundwater pollution sources is a result of improper wastewater treatment in rural settlements and excessive application of organic fertilizers at domestic kitchen-gardens and farmlands. Only few rural settlements are supplied with centralized sewerage, and construction of permeable pit latrines instead is still a common practice in rural areas (SKryZhevsKa, Y. and Karácsonyi, D. 2012).

\section{Nitrate fluxes in groundwater and rivers}

Highest-rate and most variable nitrogen fluxes were calculated for settlement areas while the lowest and the most stable values were obtained for forested lands (Figure 5).

Nitrate fluxes in settlements were derived from such point sources as pit latrines, private gardens and livestock sheds. Sewage and polluted runoff infiltrates unevenly, but poses high nitrate pollution in shallow ground waters (Bermudez-Couso, A. et al. 2013). Besides, the surface permeability is highly variable within the study area (Yakovlev, V. et al. 2015; Vystavna, Y. et al. 2015) leading to sewage percolation from pit latrines directly to the aquifer passing 


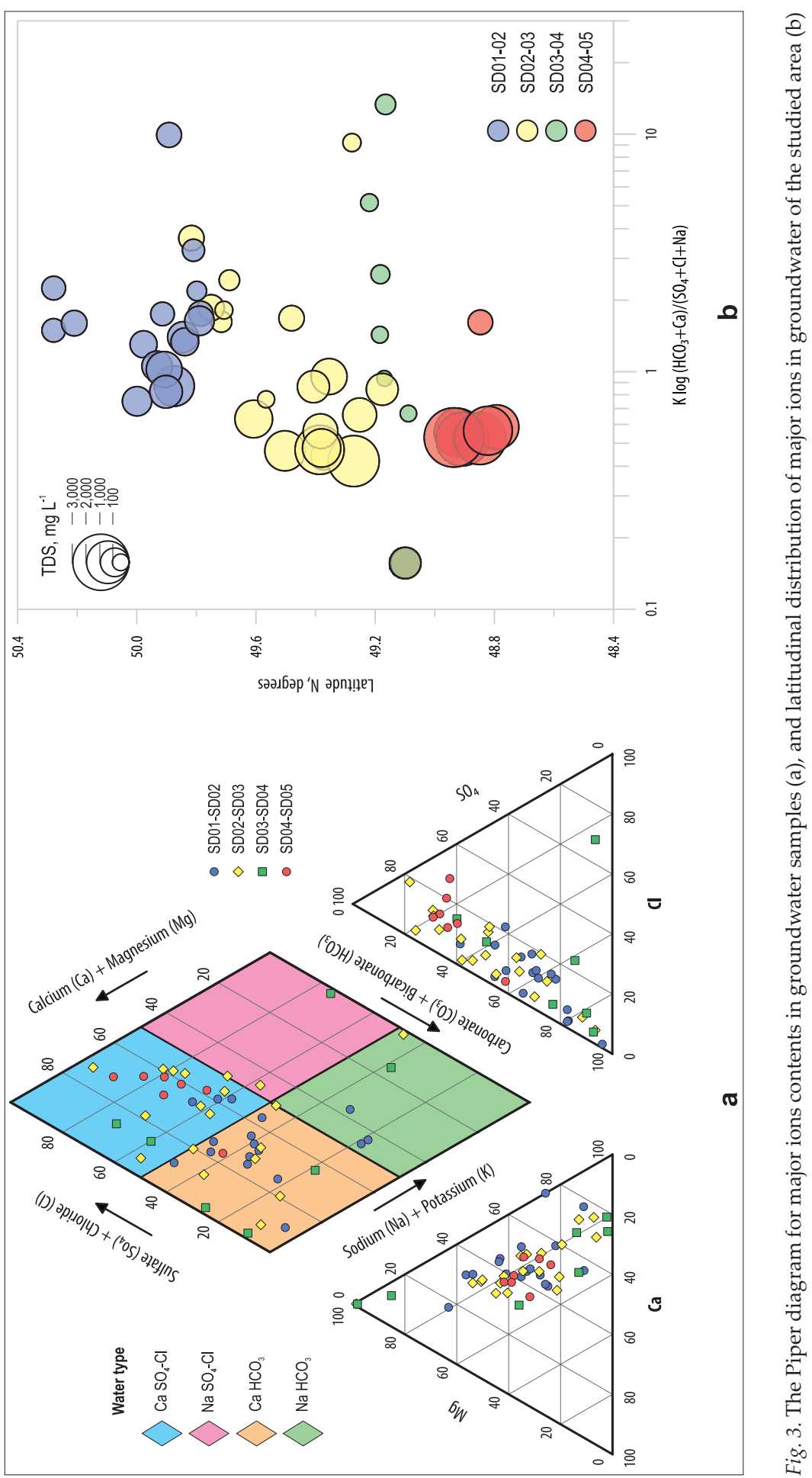




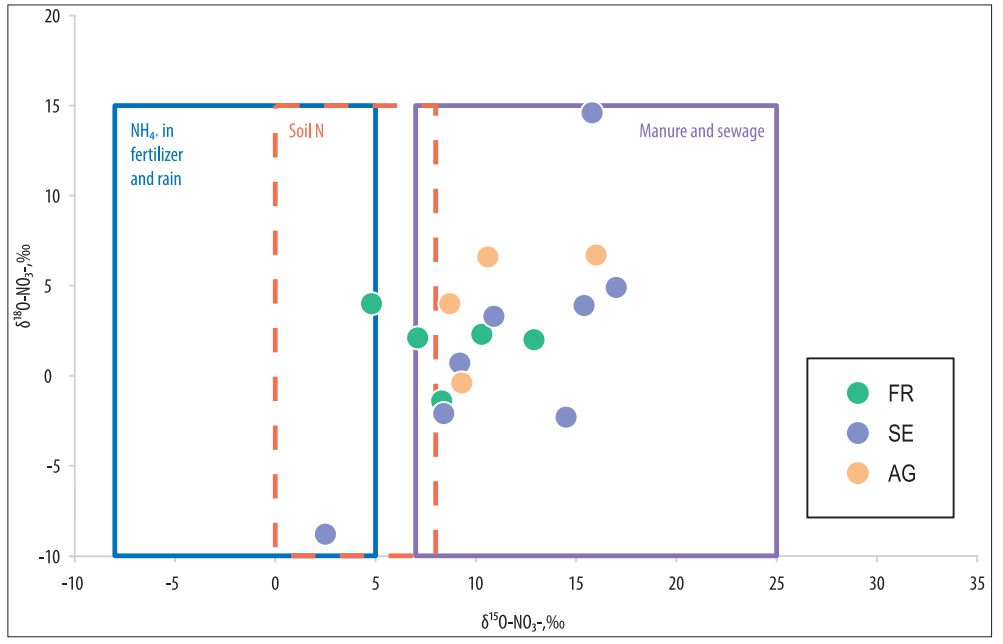

Fig. 4. Isotopic signature of nitrate in selected groundwater of agricultural (AG), forest (FR) and settlement (SE) land uses in the Kharkiv region by soil layer and vadose zone. In some cases, nitrogen is uptaken by plants, and bacterial denitrification took place; the both processes influence nitrate variations in groundwater (Vystavna, Y. et al. 2017b). The same mechanisms of intensive uptake of nitrogen by crops as well as denitrification processes explain the less amount of nitrate in groundwater in agricultural areas. Among three types of land use, forested area featured the lowest values of nitrate fluxes and less variation of nitrate concentration (see Figure 5) that can be explained by combination of denitrification, deposition and plant uptake processes in less impacted by anthropogenic activity ecosystem (Teller, A. et al. 2012).

The composition of surface water in the Seversky Donets River reflects the overall distribution of nitrate in the basin brought by groundwater, runoff and wastewater discharge (Table 1).

Calculated mass balance of substances (chloride, nitrate-N, potassium and TDS) indicated that nitrogen input occurs mainly in the upper part of the basin reaching at $150 \mathrm{~kg}$ year ${ }^{-1} \mathrm{~km}^{-2}$ while depletion of nitrate concentrations and decrease of nitrate fluxes occur

downstream. The negative values of nitrogen
Fig. 5. Annual nitrogen $\left(\mathrm{N}-\mathrm{NO}_{3}\right)$ fluxes from agricultural (AG), forest (FR) and settlement (SE) land uses (median values are shown on boxplots)

Table 1. Chloride, nitrate and potassium concentrations and discharge rates in the Seversky Donets River

\begin{tabular}{|c|c|c|c|c|c|c|c|c|c|c|}
\hline \multirow[b]{2}{*}{ Site } & \multirow[b]{2}{*}{$\mathrm{n}$} & \multicolumn{4}{|c|}{ Average concentration, $\mathrm{mg} / \mathrm{L}^{-1}$} & \multirow{2}{*}{$\begin{array}{c}\text { Water } \\
\text { discharge, } \\
\mathrm{m}^{3} \mathrm{~s}^{-1}\end{array}$} & \multicolumn{4}{|c|}{ Substances discharge, $\mathrm{t}_{\text {year }}{ }^{-1}$} \\
\hline & & $\mathrm{Cl}^{-}$ & $\mathrm{NO}_{3}^{-}$ & $\mathrm{K}^{+}$ & TDS & & $\mathrm{Cl}^{-}$ & $\mathrm{N}-\mathrm{NO}_{3}^{-}$ & $\mathrm{K}^{+}$ & TDS \\
\hline SD01 & 11 & $58 \pm 24$ & $17.4 \pm 26.8$ & $10.6 \pm 9.5$ & $719 \pm$ & 12 & 22,063 & 1,511 & 4,011 & 272,055 \\
\hline SD02 & 6 & $58 \pm 5$ & $16.5 \pm 17.7$ & $7.6 \pm 7.9$ & $765 \pm 281$ & 24 & 43,671 & 2,866 & 5,752 & 578,623 \\
\hline SD03 & 6 & $75 \pm 13$ & $7.0 \pm 4.6$ & $7.0 \pm 5.9$ & $922 \pm 85$ & 42 & 99,338 & 2,128 & 9,272 & $1,221,333$ \\
\hline SD04 & 8 & $70 \pm 15$ & $2.8 \pm 2.3$ & $6.9 \pm 4.6$ & $795 \pm 86$ & 80 & 175,592 & 1,621 & 17,408 & $2,006,446$ \\
\hline SD05 & 2 & $187 \pm 36$ & $5.5 \pm 1.5$ & $\mathrm{n} / \mathrm{m}$ & $1,227 \pm 83$ & 62 & 367,592 & 2,476 & $\mathrm{n} / \mathrm{m}$ & $2,406,416$ \\
\hline
\end{tabular}


in the middle part of the basin indicate the potential retention of nutrients (sedimentation, denitrification, plants uptake) in the ecosystem (Table 2).

Table 2. Estimated fluxes to river water from sub-catchments

\begin{tabular}{c|r|r|r|c|c}
\hline \multirow{2}{*}{$\begin{array}{c}\text { Sub- } \\
\text { catchment }\end{array}$} & \multirow{2}{*}{$\mathrm{S}, \mathrm{km}^{2}$} & \multicolumn{4}{|c}{ Estimated fluxes, $\mathrm{t} \mathrm{year}^{-1} \mathrm{~km}^{-2}$} \\
\cline { 3 - 6 } & & \multicolumn{1}{c|}{$\mathrm{Cl}^{-}$} & $\mathrm{N}^{-N_{3}}$ & $\mathrm{~K}^{+}$ & $\mathrm{TDS}$ \\
\hline SD01-SD02 & 9,013 & 2.40 & 0.150 & 0.193 & 34.0 \\
SD02-SD03 & 7,943 & 7.01 & -0.093 & 0.443 & 80.9 \\
SD03-SD04 & 10,663 & 7.15 & -0.048 & 0.763 & 73.6 \\
SD04-SD05 & 15,721 & 12.20 & 0.054 & $\mathrm{n} / \mathrm{m}$ & 25.4 \\
\hline
\end{tabular}

Beside regional lithology differences, such a distribution may be caused by significant anthropogenic inputs of nitrate and other compounds to the river. These are discharges of treated municipal wastewater from the Kharkiv metropolitan area (SD01-SD02) and inflow of salty chloride-sulphate water from the Dnipro River via the artificial canal (SD02-SD03 and SD03-SD04) (Figure 1). The increase of $\mathrm{Cl}^{-}$from upstream to downstream can be as well explained by inflow of chloride-contained wastewaters and contaminated groundwater into the surface waters. Along with that, the average concentrations of nitrate and potassium are less at downstream sites (SD03-SD05) than upstream the basin (SD01-SD02) (see Table 1).

\section{Conclusions}

Nitrate fluxes well reflected general land use structure in the Seversky Donets basin with the highest values of nitrate concentration in groundwater and surface water in settlements and agricultural lands. The application of stable isotopes of nitrate revealed the input from sewage and manure application as the most important sources of nitrate in the watershed that is used for drinking water supply. Average estimated fluxes of nitrate in groundwater are $356 \mathrm{~kg}_{\text {year }}{ }^{-1} \mathrm{~km}^{-2}$ from settlements (mostly rural) and $214 \mathrm{~kg}$ year-1 $\mathrm{km}^{-2}$ from agricultural lands. Nitrate fluxes from forested lands are estimated at $73 \mathrm{~kg}_{\text {year-1 }} \mathrm{km}^{-2}$ and derived mostly from soil nitrification and - to a less extend - from scattered households located there. Domination of manure and sewage among other groundwater pollution sources as shown by applying the stable isotope techniques is viewed as a result of improper wastewater treatment in rural settlements and excessive application of organic fertilizers at private gardens and farmlands.

Acknowledgements: The research has been carried out in the framework of the Research Project CRP F33021 "Evaluation of human impacts on water balance and nutrients dynamics in the transboundary Russia/Ukraine river basin" funded partly by the International Atomic Energy Agency (IAEA) and the O.M. Beketov National University of Urban Economy in Kharkiv (2014-2017), with partial financial support from the Shell Exploration and Production Ukraine Investments (IV) B.V. through the Donation Agreement UI55229 for studying and improvement of rural people access to clean groundwater sources in 8 districts of the Kharkiv region (2016).

\section{REFERENCES}

Bermudez-Couso, A., Fernandez-Calvino, D., Alvarez-Enjo, M.A., Simal-Gandara, J., NovoaMunoz, J.C. and Arias-Estevez, M. 2013. Pollution of surface waters by metalaxyl and nitrate from non-point sources. Science of the Total Environment 461-462. 282-289.

CAnter, L.W. 1997. Nitrates in Groundwater. New York, CRC Press Inc.

ECO 2015. Ecological and Environmental Passport of the Kharkiv region, 2015. Kiev, Ministry of the Environmental Protection of Ukraine. (in Ukrainian)

GLC 2000. Global land cover (GLC) 2000 - Europe. European Environment Agency. URL: https:// www.eea.europa.eu/data-and-maps/data/globalland-cover-2000-europe

Göndöcs, J., Breuer, H., Horváth, Á., Ács, F. and RAJKAI, K. 2015. Numerical study of the eff ect of soil texture and land use distribution on the convective precipitation. Hungarian Geographical Bulletin 64. (1): 3-15.

Katz, B.G., Chelette, A.R. and Pratt, T.R. 2004. Use of chemical and isotopic tracers to assess nitrate contamination and groundwater age, Woodville karst Plain, USA. Journal of Hydrology 289. 36-61.

Lockhart, K.M., KIng, A.M. and Harter, T. 2013. Identifying sources of groundwater nitrate contam- 
ination in a large alluvial groundwater basin with highly diversified intensive agricultural production. Journal of Contaminant Hydrology 151. 140-154.

Makovníková, J., Kanianska, R. and Kizeková, M. 2017. The ecosystem services supplied by soil in relation to land use. Hungarian Geographical Bulletin 66. (1): 37-42.

Maslov, B.S. 2009. Agricultural land improvement. Amelioration and reclamation. Vol. II. EOLSS Publications.

Matiatos, I. 2016. Nitrate source identification in groundwater of multiple land-use areas by combining isotopes and multivariate statistical analysis: A case study of Asopos basin (Central Greece). Science of The Total Environment 541. 802-814.

OuYANG, Y. 2012. Estimation of shallow groundwater discharge and nutrient load into a river. Ecological Engineering 38. (1): 101-104.

Pidlisnyuk, V., John Harrington, J.R., Melnyk, Y., Vystavna, Y. 2016. Fluctuations of annual precipitation and water resources quality in Ukraine. Chemistry and Chemical Technology 10. (4): 621-629.

RAWAT, K.S. and Singh, S.K. 2018. Water Quality Indices and GIS-based evaluation of a decadal groundwater quality. Geology, Ecology, and Landscapes 2. (4): 240-255. https://doi.org/10.1080/ 24749508.2018.1452462

Rivett, M.O., Buss, S.R., Morgan, P., Smith, J.W.N. and Bemment, C.D. 2008. Nitrate attenuation in groundwater: a review of biogeochemical controlling processes. Water Research 42. (16): 4215-4232.

SKRYZHEVSKA, Y. and KARÁcSONYI, D. 2012. Rural population in Ukraine: assessing reality, looking for revitalization. Hungarian Geographical Bulletin 61. (1): 49-78.

Slomp, C.P. and Van Cappellen, P. 2004. Nutrient inputs to the coastal ocean through submarine groundwater discharge: controls and potential impact. Journal of Hydrology 295. (1-4): 64-86.

Teller, A., Mathy, P. and Jeffers, J.N.R. 2012. Responses of forest ecosystems to environmental changes. Springer Science and Business Media.
Vystavna, Y. and Diadin, D. 2015. Water scarcity and contamination in Eastern Ukraine. IAHS-AISH Proceedings and Reports 366. 149-150.

Vystavna, Y., Diadin, D., Grynenko, V., Yakovlev, V., Vergeles, Y., Huneau, F., Rossi, P., Hejzlar, J. and KNÖLleR, K. 2017a. Determination of dominant sources of nitrate contamination in transboundary (Russia/Ukraine) catchment with heterogeneous land use. Environmental Monitoring and Assessment 189(10):509. DOI: 10.1007/s10661-017-6227-5

Vystavna, Y., Diadin, D., Yakovlev, V., Hejzlar, J., Vadillo, I., Huneau, F. and Lehmann, M.F. $2017 \mathrm{~b}$. Nitrate contamination in a shallow urban aquifer in East Ukraine: Evidence from hydrochemical, stable nitrate isotope, and land use analysis. Environmental Earth Sciences 76(13):463. DOI: 10.1007/s12665-0176796-1

Vystavna, Y., Huneau, F., Schafer, J., Motelica-Heino, M., Blanc, G., Larrose, A., Vergeles, Y., Diadin, D. and Le Coustumer, P. 2012. Distribution of trace elements in waters and sediments of the Seversky Donets transboundary watershed (Kharkiv region, Eastern Ukraine). Applied Geochemistry 27. (10): 2077-2087.

Vystavna, Y., Yakovlev, V., Diadin, D., Vergeles, Y. and Stolberg F. 2015. Hydrochemical characteristics and water quality assessment of surface and ground waters in the transboundary (Russia/ Ukraine) Seversky Donets basin. Environmental Earth Sciences 74. (1): 585-596.

WHO 2008. Guidelines for drinking water quality. $3^{\text {rd }}$ edition. World Health Organization. Geneva, WHO Press.

WHO 2011. Nitrate and nitrite in drinking water. Background document for development of WHO guidelines for drinking water quality. World Health Organization. Geneva, WHO Press.

Yakovlev, V., Vystavna, Y., Diadin, D. and Vergeles, Y. 2015. Nitrates in springs and rivers of East Ukraine: Distribution, contamination and fluxes. Applied Geochemistry 53. 71-78. 
